\title{
Control of Trace Metal Emissions During Coal Combustion
}

\author{
Quarterly Report \\ October 1 - December 31, 1996
}

\author{
By \\ Thomas C. Ho
}

Work Performed Under Contract No.: DE-FG22-94PC94221

\author{
For \\ U.S. Department of Energy \\ Office of Fossil Energy \\ Federal Energy Technology Center \\ P.O. Box 880 \\ Morgantown, West Virginia 26507-0880 \\ By \\ Lamar University \\ Beaumont, Texas 77710
}




\section{Disclaimer}

This report was prepared as an account of work sponsored by an agency of the United States Government. Neither the United States Government nor any agency thereof, nor any of their employees, makes any warranty, express or implied, or assumes any legal liability or responsibility for the accuracy, completeness, or usefulness of any information, apparatus, product, or process disclosed, or represents that its use would not infringe privately owned rights. Reference herein to any specific commercial product, process, or service by trade

name, trademark, manufacturer, or otherwise does not necessarily constitute or imply its endorsement, recommendation, or favoring by the United States Government or any agency thereof. The views and opinions of authors expressed herein do not necessarily state or reflect those of the United States Government or any agency thereof. 


\title{
TECHNICAL PROGRESS REPORT
}

\section{(October 1, 1996 through December 31, 1996)}

\author{
Prepared \\ for the Project

\section{CONTROL OF TRACE METAL EMISSIONS DURING COAL COMBUSTION}

Thomas C. Ho

Department of Chemical Engineering

Lamar University

Beaumont, Texas

January 1997

\author{
Prepared by \\ LAMAR UNIVERSITY \\ Beaumont, Texas 77710 \\ for the \\ U.S. DEPARTMENT OF ENERGY \\ PITTSBURGH ENERGY TECHNOLOGY CENTER \\ under Grant No. DE-FG22-94PC94221--10
}


Disclaimer. This report was prepared as an account of work sponsored by an agency of the United States Government. Neither the United States Government nor any agency thereof, nor any of their employees, makes any warranty, express or implied, or assumes any legal liability or responsibility for the accuracy, completeness, or usefulness of any information, apparatus, product, or process disclosed, or represents that its use would not infringe privately owned right. Reference herein to any specific commercial product, process, or service by trade name, trademark, manufacturer, or otherwise does not necessarily constitute or imply its endorsement, recommendation, or favoring by the United States Government or any agency thereof. The views and opinions of authors expressed herein do not necessarily state or reflect those of the United States Government or any agency thereof.

Measurement Units. All reports to be delivered under this instrument shall use the SI Metric System of Units as the primary units of measure. When reporting units in all reports, primary SI units shall be followed by their U.S. Customary Equivalents in Parentheses ( ). The grantee shall insert the text of this clause, including this paragraph, in all subgrants or subcontracts under this grant. Note: SI is an abbreviation for "Le Systeme International d'Unites." 
TECHNICAL PROGRESS REPORT

October 1, 1996 through December 31, 1996

Project Title: CONTROL OF TRACE METAL EMISSIONS DURING COAL COMBUSTION

DOE Grant Number:

Principal Investigator:

DOE Project Officer:
DE-FG22-94PC94221

Thomas C. Ho, Lamar University

Mike Baird, PETC

\begin{abstract}
Emissions of toxic trace metals in the form of metal fumes or submicron particulates from a coal-fired combustion source have received greater environmental and regulatory concern over the past years. Current practice of controlling these emissions is to collect them at the cold-end of the process by airpollution control devices (APCDs) such as electrostatic precipitators and baghouses. However, trace metal fumes may not always be effectively collected by these devices because the formed fumes are extremely small.
\end{abstract}

The proposed research is to explore the opportunities for improved control of toxic trace metal emissions, alternatively, at the hot-end of the coal combustion process, i.e., in the combustion chamber. The technology proposed is to prevent the metal fumes from forming during the process, which would effectively eliminate the metal emission problems. Specifically, the technology is to employ suitable sorbents to (1) reduce the amount of metal volatilization during combustion and (2) capture volatilized metal vapors. The objectives of the project are to demonstrate the technology and to characterize the metal capture process during coal combustion in a fluidized bed combustor.

The project was started on July 1, 1994 and this is the tenth quarterly technical progress report. Specifically, the following progress has been made during this performance period from October 1, 1996 through December 31, 1996:

1. Metal Capture Experiments Continued - Additional combustion experiments involving seven different coal samples were carried out to obtain more statistically representative results.

2. Additional Results Obtained - Additional metal capture results were obtained and were added into the existing database. The metals involved included lead, cadmium, chromium, arsenic, and selenium.

3. Paper Presented - An invited paper, entitled "Trace Metal Capture by Various Sorbents during Fluidized Bed Coal Combustion," was presented at the Fifth Asian Conference on Fluidization and Three-Phase Reactors held in Hsitou, Taiwan, December 16-20, 1996.

4. Presentation Accepted - An updated version of the above presented paper was accepted for presentation at the 22nd International Technical Conference on Coal Utilization \& Fuel Systems to be held in Clearwater, Florida, March 16-19, 1997. 


\section{TABLE OF CONTENTS}

EXECUTIVE SUMMARY 1

INTRODUCTION 2

RESULTS AND DISCUSSION 3

CONCLUSIONS 5

REFERENCES

\section{TABLES}

Table 1. Sulfur, Chlorine and Target Metals in Coal Samples 6

Table 2. Major Composition, Trace Metal Concentration and Fluidization Properties of the Three Tested Sorbents 7

Table 3. $\quad$ Experimental Parameters and Operating Conditions 8

Table 4. Equilibrium Simulation Results for Lead with or without Sulfur

Table 5. Equilibrium Simulation Results for Cadmium with or without Sulfur

Table 6. $\quad$ Percentage Lead Capture by Sorbents (\%) 11

Table 7. Percentage Cadmium Capture by Sorbents (\%) 12

Table 8. Percentage Chromium Capture by Sorbents (\%) 13

Table 9. Percentage Arsenic Capture by Sorbents (\%) 14

Table 10. Percentage Selenium Capture by Sorbents (\%) 15 


\section{EXECUTIVE SUMMARY}

Toxic (or potentially toxic) trace metallic elements such as barium, beryllium, boron, cadmium, chromium, lead, mercury, nickel, selenium, strontium, vanadium, zinc and zirconium are usually contained in coal in various forms. These metals will either stay in the ash or be vaporized during high temperature combustion. Portions of the vaporized metals may eventually be emitted from a combustion system. Most of the emitted metals will be in the form of metal fumes or particulates with diameters less than 1 micron and are potentially hazardous to the environment. The U.S. EPA has reported that metals account for almost all of the identified risks from waste incineration systems.

Concern over toxic trace metal emissions from coal-fired combustion sources is growing, especially as the result of the passage of the 1990 Clean Air Act Amendments (CAAA). To address the concern, the U.S. DOE has recently co-sponsored a workshop jointly with the Electric Power Research Institute (EPRI) and the Energy and Environmental Research Center (EERC) on Trace Elements Transformations in Coal-Fired Power Plants. The objective of the workshop was to evaluate the current level of understanding on metal behavior during coal combustion and to identify potential technologies for improved metal emission control.

Current practice of controlling trace metal emissions during coal combustion employs conventional air pollution control devices (APCDs), e.g., venturi scrubbers, electrostatic precipitators, baghouses etc., to collect fly ash and metal fumes. This type of control is essentially a cold-end control because metals are allowed to vaporize and condense before being controlled. The control may not always be effective on metal fumes due to their extremely fine sizes.

An alternative technology for metal emission control is to minimize the formation of metal fumes at the hot-end of the coal combustion process, i.e., in the combustion chamber. The technology proposed is to prevent the metal fumes from forming during the process, which would effectively eliminate the metal emission problems. Specifically, the technology is to employ suitable sorbents to (1) reduce the amount of metal volatilization during combustion and (2) capture volatilized metal vapors. The objectives of the project are to demonstrate the technology and to characterize the metal capture process during coal combustion in a fluidized bed combustor.

The project was started on July 1, 1994 and this is the tenth quarterly technical progress report. Specifically, the following progress has been made during this performance period from October 1, 1996 through December 31, 1996:

1. Metal Capture Experiments Continued - Additional combustion experiments involving seven different coal samples were carried out to obtain more statistically representative results.

2. Additional Results Obtained - Additional metal capture results were obtained and were added into the existing database. The metals involved included lead, cadmium, chromium, arsenic, and selenium. 
3. Paper Presented - An invited paper, entitled "Trace Metal Capture by Various Sorbents during Fluidized Bed Coal Combustion," was presented at the Fifth Asian Conference on Fluidization and Three-Phase Reactors held in Hsitou, Taiwan, December 16-20, 1996.

4. Presentation Accepted - An updated version of the above presented paper was accepted for presentation at the 22nd International Technical Conference on Coal Utilization \& Fuel Systems to be held in Clearwater, Florida, March 16-19, 1997.

\section{INTRODUCTION}

Toxic trace metallic elements such as arsenic, cadmium, chromium, lead, mercury, and selenium are usually contained in coal in various forms and trace amounts. Portions of these metals may eventually be emitted from a combustion system in the form of metal fumes or particulates with diameters less than 1 micron, which are potentially hazardous to the environment (Davidson et al., 1974). Current practice of controlling trace metal emissions during coal combustion employs conventional air pollution control devices (APCDs), such as electrostatic precipitators and baghouses, to collect fly ash and metal fumes. The control may not always be effective on metal fumes due to their extremely fine sizes (Oppelt, 1987).

Concern over toxic trace metal emissions from coal-fired combustion sources is growing, especially as the result of the passage of the 1990 Clean Air Act Amendments (CAAA) where eleven metallic elements, i.e., antimony, arsenic, beryllium, cadmium, chromium, cobalt, lead, manganese, mercury, nickel, and selenium are listed as potential hazardous air pollutants. This study is to explore the opportunities for improved control of toxic trace metal emissions from coal-fired combustion systems. Specifically, the technology proposed is to employ suitable sorbents to (1) reduce the amount of metal volatilization and (2) capture volatilized metal vapors during fluidized bed coal combustion. The objectives of the project were to demonstrate the capture process, identify effective sorbents, and characterize the capture efficiency.

\section{Scientific Discussion}

Chemical absorption reactions between metal vapors and a variety of sorbents at high temperatures have been observed both in a packed bed and in a fluidized bed (see, e.g., Uberol and Shadman, 1990; Ho et al., 1992, 1994). The following reactions between metals and sorbent constituents have been confirmed both theoretically and experimentally:

$$
\begin{aligned}
& 2 \mathrm{PbO}+\mathrm{SiO}_{2}---->\mathrm{Pb}_{2} \mathrm{SiO}_{4}(\mathrm{~s}) \\
& \mathrm{CdO}+\mathrm{SiO}_{2}---->\mathrm{CdSiO}_{3}(\mathrm{~s}) \\
& \mathrm{CdO}+\mathrm{Al}_{2} \mathrm{O}_{3}---->\mathrm{CdAl}_{2} \mathrm{O}_{4}(\mathrm{~s}) \\
& \mathrm{PbCl}{ }_{2}+\mathrm{Al}_{2} \mathrm{O}_{3}: 2 \mathrm{SiO}_{2}+\mathrm{H}_{2} \mathrm{O}---->\mathrm{PbO}_{2} \mathrm{Al}_{2} \mathrm{O}_{3}: 2 \mathrm{SiO}_{2}(\mathrm{~s})+2 \mathrm{HCl}(\mathrm{g}) \\
& \mathrm{CdCl}_{2}+\mathrm{Al}_{2} \mathrm{O}_{3}+\mathrm{H}_{2} \mathrm{O}---->\mathrm{CdAl}_{2} \mathrm{O}_{4}(\mathrm{~s})+2 \mathrm{HCl}(\mathrm{g})
\end{aligned}
$$

The technology of metal capture by sorbents, however, has never been evaluated during fluidized bed coal combustion. 


\section{Equilibrium Calculation}

Equilibrium composition represents the most stable chemical composition within a system under a specific state. Thermodynamically, this composition is corresponding to the one where the system free energy is minimized. The calculated equilibrium composition would reveal the preferred chemical speciation under a specific state, which in turn, suggest potential chemical reactions which may occur within the system. In this study, combustion equilibrium was calculated using a PC-based computer software package (Ho, 1996) especially developed for predicting equilibrium compositions during fuel or waste combustion.

\section{Experimental}

Metal capture experiments were carried out semi-batchwise in a $25.4 \mathrm{~mm}$ (1") OD quartz fluidized bed coal combustor enclosed in an electric furnace. Seven coal samples from the Illinois Basin Coal Sample Bank (IBCSB) were tested in the experiments. The concentration of sulfur, chlorine, and the target metals in these sample was summarized in Table 1. The sorbents tested included bauxite, zeolite and lime. Their chemical composition and the corresponding minimum fluidization velocity $\left(\mathrm{U}_{\mathrm{mf}}\right)$ at $900^{\circ} \mathrm{C}$ are listed in Table 2.

In an experimental run, a bed of sorbent was preheated to the desired temperature under the designed operating conditions. A predetermined amount of coal was then charged in the bed at a constant feed rate for combustion. After the combustion was completed, the bed residue including sorbent and ash was discharged and separated for analysis of metal concentration. The experimental parameters and operating conditions are summarized in Table 3.

Metal concentration in coal, original sorbent, and combustor residue was determined by an atomic absorption spectrophotometer. An HF modified EPA Method 3050 was used to digest metals from the sorbent, which involves the use of $\mathrm{HNO}_{3}, \mathrm{HCl}$ and $\mathrm{HF}$ acids. Toxicity Characteristics Leaching Procedure (TCLP) tests were performed to determine the leachability of the captured metals from sorbents.

\section{RESULTS AND DISCUSSION}

\section{Simulation Results}

Two typical sets of simulation results indicating potential metal-sorbent reactions and the effect of sulfur on metal capture by sorbents are shown in Tables 4 and 5, for lead and cadmium, respectively. The corresponding elemental composition and combustion conditions used in the simulations were: carbon - $71.3 \mathrm{wt} \%$, hydrogen - $5.2 \mathrm{wt} \%$, nitrogen - $1.4 \mathrm{wt} \%$, oxygen -12.4 to $7.8 \mathrm{wt} \%$, sulfur - 0 to $4.6 \mathrm{wt} \%$, metal concentration - $50 \mathrm{ppm}$, ash - $9.3 \mathrm{wt} \%$, combustion temperature $-900^{\circ} \mathrm{C}$, and percent excess air $-50 \%$.

The results shown in Table 4 indicate that lead will react with both sulfur and silica during combustion. At a temperature below $950^{\circ} \mathrm{C}, \mathrm{PbSO}_{4}(\mathrm{~s})$ is the thermodynamically preferred lead compound; 
however, between $950^{\circ} \mathrm{C}$ and $1000^{\circ} \mathrm{C}, \mathrm{PbSiO}_{4}(\mathrm{~s})$ is the preferred one; and, above $1000^{\circ} \mathrm{C}, \mathrm{PbO}(\mathrm{g})$ is the dominating species. These results suggest that silica is thermodynamically capable of capturing lead. However, the existence of sulfur will affect the capture process especially at a temperature below $950^{\circ} \mathrm{C}$. Note that lead does not seem to react with $\mathrm{Al}_{2} \mathrm{O}_{3}$ according to the equilibrium simulation. It should also be pointed out that lead does not show any reactions with $\mathrm{CaO}$ because there are no thermodynamic data available in the literature.

The results shown in Table 5 for cadmium indicate that cadmium will react with $\mathrm{Al}_{2} \mathrm{O}_{3}$ and $\mathrm{SiO}_{2}$ to form $\mathrm{CdAl}_{2} \mathrm{O}_{4}(\mathrm{~s})$ and $\mathrm{CdSiO}_{3}(\mathrm{~s})$, respectively. It, however, will not react with $\mathrm{CaO}$. The existence of sulfur does not seem to interfere with the reactions according to the equilibrium results shown in the table. These simulation results, again, suggest that silica and alumina have potential to capture cadmium under the combustion conditions. Note that, although not shown, the simulation results for chromium have indicated that the thermodynamically preferred chromium compound under the combustion conditions is exclusively $\mathrm{Cr}_{2} \mathrm{O}_{3}$ (s) and no chromium-sorbent compounds are observed. The results suggest that, thermodynamically, the tested sorbents are not expected to chemically absorb chromium during combustion.

\section{Experimental Results}

Typical experimental results indicating the effectiveness of metal capture by various sorbents are shown in Tables 6, through 10 for lead, cadmium, chromium, arsenic, and selenium, respectively. The results shown in Table 6 for lead indicate that all three sorbents tested are capable of capturing lead during fluidized bed combustion with the average capture efficiency ranging from $46 \%$ to $72 \%$. Zeolite and bauxite are seen to be more effective than lime. As suggested by equilibrium simulations, the mechanism of lead capture by zeolite appears to be due to the formation of $\mathrm{Pb}_{2} \mathrm{SiO}_{4}(\mathrm{~s})$ and the mechanism of lead capture by bauxite may be due to the formation of the same compound or an alumino-silica compound. The mechanism of lead capture by lime, however, may be due to the "melt capture" as suggested by Linak and Wendt (1993).

For cadmium capture, the results shown in Table 7 indicate that the average capture efficiency associated with a sorbent is very similar to that of lead capture by the sorbent. Zeolite and bauxite again are seen to be more effective than lime, suggesting the formation of $\mathrm{CdAl}_{2} \mathrm{O}_{4}(\mathrm{~s})$ and $\mathrm{CdSiO}_{3}(\mathrm{~s})$ based on equilibrium simulations. The formation of these compounds, however, could not be analytically confirmed due to their low concentrations in the sorbents.

The chromium capture results shown in Table 8 indicate that zeolite and lime are both capable of capturing the metal. The average capture efficiencies are seen to be from $14 \%$ to $29 \%$ which are much lower than those of lead and cadmium capture. The mechanisms of chromium capture by these sorbents, however, are not clear at this time. Efforts are currently devoted to analytically identify the chromium state in the sorbents. Note that bauxite was not observed to capture any chromium because the original bauxite contained a high concentration of chromium which continued to vaporize during combustion. The net result was that, in contrast to chromium capture, bauxite gave away chromium during the process. 
The arsenic and selenium capture results shown in Tables 9 and 10 indicate that the capture of these two metals by sorbents is not as effective as that of lead, cadmium, and chromium. The average capture efficiency is in the range of 13 to $34 \%$ as indicated in the tables. Additional experiments are currently being carried out to confirm the results.

Although not shown, it was observed that the amount of lead and cadmium capture by a unit mass of sorbents was found to be roughly proportional to the concentration of the metal in coal. This, however, was not observed for chromium capture by sorbents. Note that, the observed results have not clearly indicated the effects of sulfur and other coal properties on capture efficiency of the metal capture process.

\section{CONCLUSIONS}

This project investigated the potential of employing suitable sorbents to capture toxic trace metals during fluidized bed coal combustion. The experimental results observed so far indicated that metal capture by sorbents can be as high as $91 \%$ depending on the metal species and sorbent involved. All three sorbents tested, i.e., bauxite, zeolite and lime, were observed to be capable of capturing lead and cadmium in a various degree, and zeolite and lime were able to capture chromium. The capture of arsenic and selenium by sorbents, however, is less effective. Results from thermodynamic equilibrium simulations suggested the formation of metal-sorbent compounds such as $\mathrm{Pb}_{2} \mathrm{SiO}_{4}(\mathrm{~s}), \mathrm{CdAl}_{2} \mathrm{O}_{4}(\mathrm{~s})$ and $\mathrm{CdSiO}_{3}(\mathrm{~s})$ under the combustion conditions. Additional experiments, however, are needed to obtain more statistically representative results.

\section{REFERENCES}

Davidson, R. L., Natush, D. F. S., Wallace, J. R., and Evans, C. A., ES\&T, 8, 1107 (1974).

Ho, T. C., C. H. Chen, J. R. Hopper and D. Oberacker, CS\&T, 85, 101 (1992).

Ho, T. C., H. T. Lee, H. W. Chu and J. R. Hopper, Fuels Processing T., 39, 373 (1994).

Ho, T. C., Incineration Equilibrium IECP, CEP Software Directory, 68 (1996).

Linak, William P. and Jost O. L. Wendt, Prog. Energy Combust. Sci., 19, 145 (1993).

Oppelt, E. T., JAPCA, 37, 558 (1987).

Uberol, M. and F. Shadman, AIChE J., 36, 307 (1990). 
Table 1. Sulfur, Chlorine and Target Metals in Coal Samples (Units: \% for $\mathrm{S}$ and $\mathrm{Cl}$, ppm for metals)

\begin{tabular}{lccccc}
\hline CoallElement & $\mathrm{S}$ & $\mathrm{Cl}$ & $\mathrm{Cd}$ & $\mathrm{Cr}$ & $\mathrm{Pb}$ \\
& & & & & \\
\hline IBC-101 & 4.4 & 0.1 & 1.1 & 31 & 8 \\
IBC-102 & 3.3 & 0.0 & 0.8 & 7 & 149 \\
IBC-106 & 3.8 & 0.0 & 0.2 & 10.4 & 6 \\
IBC-109 & 1.2 & 0.4 & $<0.3$ & 13 & 18 \\
IBC-110 & 4.6 & 0.0 & $<0.4$ & 11 & 10 \\
IBC-111 & 2.0 & 0.0 & $<0.4$ & 14 & 18 \\
IBC-112 & 2.8 & 0.2 & $<0.3$ & 14 & 27 \\
\hline
\end{tabular}


Table 2. Major Composition, Trace Metal Concentration and Fluidization Properties of the Three Tested Sorbents

\begin{tabular}{|c|c|c|c|}
\hline $\begin{array}{l}\text { Composition } \\
\text { or } \\
\text { Property }\end{array}$ & Bauxite & Zeolite & Lime \\
\hline $\mathrm{SiO}_{2}(\%)$ & 9.0 & 66.7 & 0.7 \\
\hline $\mathrm{Al}_{2} \mathrm{O}_{3}(\%)$ & 78.0 & 12.1 & 0.3 \\
\hline $\mathrm{CaO}(\%)$ & 0.0 & 3.1 & 97.2 \\
\hline $\mathrm{Cd}(\mathrm{ppm})$ & 2.0 & 3.0 & 3.6 \\
\hline $\mathrm{Cr}(\mathrm{ppm})$ & 146 & 4.0 & 7.8 \\
\hline $\mathrm{Pb}(\mathrm{ppm})$ & 43.2 & 60.4 & 72.4 \\
\hline $\mathrm{d}_{\mathrm{p}}(\mathrm{mm})$ & 0.5 & 0.5 & 0.5 \\
\hline $\mathrm{U}_{\mathrm{mf}}(\mathrm{cm} / \mathrm{s})$ & 3.8 & 3.5 & 3.8 \\
\hline
\end{tabular}


Table 3. Experimental Parameters and Operating Conditions

\begin{tabular}{ll}
\hline Parameter & Range \\
\hline Coal Size & $2.0-2.8 \mathrm{~mm}$ \\
Coal Amount & $60 \mathrm{~g}$ \\
Coal Feed Rate & $0.22 \mathrm{~g} / \mathrm{min}$ \\
Sorbent Size & $0.4-0.6 \mathrm{~mm}$ \\
Sorbent Amount & $22.5-30 \mathrm{~g}$ \\
Static Sorbent Height & $6 \mathrm{~cm}$ \\
Air Flow Rate & $3 \mathrm{U} \mathrm{mf}$ of Sorbent \\
Combustor Temperature & $900^{\circ} \mathrm{C}$ \\
Combustion Duration & $4.5 \mathrm{hrs}$ \\
\hline
\end{tabular}


Table 4. Equilibrium Simulation Results for Lead with or without Sulfur

\begin{tabular}{|c|c|c|c|c|c|}
\hline \multirow{2}{*}{$\begin{array}{c}\begin{array}{c}\text { Sorbent } \\
\text { Constituent }\end{array} \\
\mathrm{SiO}_{2}\end{array}$} & \multicolumn{2}{|r|}{ Metal } & \multirow{2}{*}{$\begin{array}{c}\begin{array}{c}\text { With or Without } \\
\text { Sulfur }\end{array} \\
\text { Without } \mathrm{S}\end{array}$} & \multicolumn{2}{|c|}{$\begin{array}{l}\text { Sulfur-Metal-Sorbent } \\
\text { Compound }\end{array}$} \\
\hline & $\mathrm{Pb}$ & & & $\mathrm{Pb}_{2} \mathrm{SiO}_{4}(\mathrm{~s})$ & $<1000^{\circ} \mathrm{C}$ \\
\hline & & & & $\mathrm{PbO}(\mathrm{g})$ & $>1000^{\circ} \mathrm{C}$ \\
\hline & & & With S & $\mathrm{PbSO}_{4}(\mathbf{s})$ & $<950^{\circ} \mathrm{C}$ \\
\hline & & & & $\mathrm{Pb}_{2} \mathrm{SiO}_{4}(\mathrm{~s})$ & $<1000^{\circ} \mathrm{C}$ \\
\hline & & & & $\mathrm{PbO}(\mathrm{g})$ & $>1000^{\circ} \mathrm{C}$ \\
\hline \multirow[t]{4}{*}{$\mathrm{Al}_{2} \mathrm{O}_{3}$} & & $\mathrm{~Pb}$ & Without S & $\mathrm{PbO}(\mathrm{s})$ & $<900^{\circ} \mathrm{C}$ \\
\hline & & & & $\mathrm{PbO}(\mathrm{g})$ & $>900^{\circ} \mathrm{C}$ \\
\hline & & & With S & $\mathrm{PbSO}_{4}(\mathrm{~s})$ & $<950^{\circ} \mathrm{C}$ \\
\hline & & & & $\mathrm{PbO}(\mathrm{g})$ & $>950^{\circ} \mathrm{C}$ \\
\hline \multirow[t]{5}{*}{$\mathrm{CaO}$} & $\mathrm{Pb}$ & & Without S & $\mathrm{PbO}(\mathrm{s})$ & $<900^{\circ} \mathrm{C}$ \\
\hline & & & & $\mathrm{PbO}(\mathrm{g})$ & $>900^{\circ} \mathrm{C}$ \\
\hline & & & With S & $\mathrm{CaSO}_{4}(\mathrm{~s})$ & $>500^{\circ} \mathrm{C}$ \\
\hline & & & & $\mathrm{PbSO}_{4}(\mathrm{~s})$ & $<950^{\circ} \mathrm{C}$ \\
\hline & & & & $\mathrm{PbO}(\mathrm{g})$ & $>950^{\circ} \mathrm{C}$ \\
\hline
\end{tabular}


Table 5. Equilibrium Simulation Results for Cadmium with or without Sulfur

\begin{tabular}{|c|c|c|c|c|}
\hline $\begin{array}{l}\text { Sorbent } \\
\text { Constituent }\end{array}$ & Metal & $\begin{array}{c}\text { With or Without } \\
\text { Sulfur }\end{array}$ & \multicolumn{2}{|c|}{$\begin{array}{l}\text { Sulfur-Metal-Sorbent } \\
\text { Compound }\end{array}$} \\
\hline \multirow[t]{6}{*}{$\mathrm{SiO}_{2}$} & $\mathrm{Cd}$ & Without S & $\mathrm{CdSiO}_{3}(\mathrm{~s})$ & $<850^{\circ} \mathrm{C}$ \\
\hline & & & $\mathrm{CdO}(\mathrm{s})$ & $<1000^{\circ} \mathrm{C}$ \\
\hline & & & $\mathrm{Cd}(\mathrm{g})$ & $>1000^{\circ} \mathrm{C}$ \\
\hline & & With S & $\mathrm{CdSO}_{4}(\mathrm{~s})$ & $<800^{\circ} \mathrm{C}$ \\
\hline & & & $\mathrm{CdO}(\mathrm{s})$ & $<900^{\circ} \mathrm{C}$ \\
\hline & & & $\operatorname{CdS}(\mathrm{g})$ & $>900^{\circ} \mathrm{C}$ \\
\hline \multirow[t]{5}{*}{$\mathrm{Al}_{2} \mathrm{O}_{3}$} & $\mathrm{Cd}$ & Without S & $\mathrm{CdAl}_{2} \mathrm{O}_{4}(\mathrm{~s})$ & $<950^{\circ} \mathrm{C}$ \\
\hline & & & $\mathrm{CdO}(\mathrm{s})$ & $<1000^{\circ} \mathrm{C}$ \\
\hline & & & $\mathrm{Cd}(\mathrm{g})$ & $>1000^{\circ} \mathrm{C}$ \\
\hline & & With S & $\mathrm{CdAl}_{2} \mathrm{O}_{4}(\mathrm{~s})$ & $<950^{\circ} \mathrm{C}$ \\
\hline & & & $\operatorname{CdS}(\mathrm{g})$ & $>950^{\circ} \mathrm{C}$ \\
\hline \multirow[t]{5}{*}{$\mathrm{CaO}$} & $\mathrm{Cd}$ & Without S & $\mathrm{CdO}(\mathrm{s})$ & $<1000^{\circ} \mathrm{C}$ \\
\hline & & & $\mathrm{Cd}(\mathrm{g})$ & $>1000^{\circ} \mathrm{C}$ \\
\hline & & With S & $\mathrm{CaSO}_{4}(\mathrm{~s})$ & $>500^{\circ} \mathrm{C}$ \\
\hline & & & $\mathrm{CdO}(\mathrm{s})$ & $<900^{\circ} \mathrm{C}$ \\
\hline & & & $\operatorname{CdS}(\mathrm{g})$ & $>900^{\circ} \mathrm{C}$ \\
\hline
\end{tabular}


Table 6. Percentage Lead Capture by Sorbents (\%)

\begin{tabular}{cccc}
\hline Coal Sorbent & Bauxite & Zeolite & Lime \\
\hline IBC-101 & 84 & 63 & 86 \\
IBC-102 & 76 & 83 & 17 \\
IBC-106 & 83 & 52 & 67 \\
IBC-109 & 65 & 64 & 68 \\
IBC-110 & 77 & 60 & 28 \\
IBC-111 & 40 & 91 & 32 \\
IBC-112 & 81 & 51 & 21 \\
\hline Average & $\mathbf{7 2}$ & $\mathbf{6 6}$ & $\mathbf{4 6}$ \\
\hline & & & \\
\hline
\end{tabular}


Table 7. Percentage Cadmium Capture by Sorbents (\%)

\begin{tabular}{|c|c|c|c|}
\hline CoallSorbent & Bauxite & Zeolite & Lime \\
\hline IBC-101 & 46 & 47 & 32 \\
\hline IBC-102 & 38 & 53 & 26 \\
\hline IBC-106 & 76 & 86 & 81 \\
\hline IBC-109 & 54 & 86 & 46 \\
\hline IBC-110 & 66 & 64 & 42 \\
\hline IBC-111 & 74 & 22 & 57 \\
\hline IBC-112 & 72 & 85 & 21 \\
\hline Average & 61 & 63 & 44 \\
\hline
\end{tabular}


Table 8. Percentage Chromium Capture by Sorbents (\%)

\begin{tabular}{|c|c|c|c|}
\hline CoallSorbent & Bauxite & Zeolite & Lime \\
\hline IBC-101 & 0 & 7 & 4 \\
\hline IBC-102 & 0 & 51 & 37 \\
\hline IBC-106 & 0 & 26 & 13 \\
\hline IBC-109 & 0 & 25 & 22 \\
\hline IBC-110 & 0 & 57 & 7 \\
\hline IBC-111 & 0 & 19 & 4 \\
\hline IBC-112 & 0 & 17 & 13 \\
\hline Average & $\mathbf{0}$ & 29 & 14 \\
\hline
\end{tabular}


Table 9. Percentage Arsenic Capture by Sorbents (\%)

\begin{tabular}{|c|c|c|c|}
\hline CoallSorbent & Bauxite & Zeolite & Lime \\
\hline IBC-101 & 57 & 24 & 10 \\
\hline IBC-102 & 19 & 7 & 30 \\
\hline IBC-106 & 28 & 14 & 15 \\
\hline IBC-109 & 34 & 13 & 7 \\
\hline IBC-110 & 32 & 19 & 21 \\
\hline IBC-111 & 28 & 18 & 17 \\
\hline IBC-112 & 43 & 22 & 14 \\
\hline Average & 34 & 17 & 16 \\
\hline
\end{tabular}


Table 10. Percentage Selenium Capture by Sorbents (\%)

\begin{tabular}{cccc}
\hline CoallSorbent & Bauxite & Zeolite & Lime \\
\hline IBC-101 & 29 & 28 & 24 \\
IBC-102 & 18 & 9 & 16 \\
IBC-106 & 9 & 8 & 10 \\
IBC-109 & 43 & 11 & 12 \\
IBC-110 & 12 & 3 & 12 \\
IBC-111 & 18 & 24 & 22 \\
IBC-112 & 8 & 10 & 12 \\
\hline Average & $\mathbf{2 0}$ & $\mathbf{1 3}$ & $\mathbf{1 5}$ \\
\hline
\end{tabular}

